\title{
Irish Review (Dublin)
}

\author{
A Celtic Miscellany \\ Author(s): P. C. \\ Source: The Irish Review (Dublin), Vol. 3, No. 27 (May, 1913), pp. 154-157 \\ Published by: Irish Review (Dublin) \\ Stable URL: http://www.jstor.org/stable/30063270 \\ Accessed: $15 / 06 / 2014$ 04:34
}

Your use of the JSTOR archive indicates your acceptance of the Terms \& Conditions of Use, available at http://www.jstor.org/page/info/about/policies/terms.jsp

JSTOR is a not-for-profit service that helps scholars, researchers, and students discover, use, and build upon a wide range of content in a trusted digital archive. We use information technology and tools to increase productivity and facilitate new forms of scholarship. For more information about JSTOR, please contact support@ jstor.org. 


\section{A CELTIC MISCELLANY*}

$\mathbf{I}^{\mathrm{T}}$ is hard to imagine a publisher in Ireland or Great Britain undertaking the production of a miscellany that makes a volume of five hundred pages, the contents of which are in Irish, ScotsGaelic, Welsh, English, French and German. In the case of the less well-known languages, the typographical difficulties must have been considerable, and they were probably increased by the fact that one of the editors was in Dublin while the other remained in Christiana. Celtic studies which owe so much to the German Professors are now under obligation to a German publisher, Herr Max Niemeyer, of Halle, a.S., and to his printers. With the exception of Dr. Meyer himself, every living authority on Celtic literature, history and scholarship, has contributed to the Miscellany, and the result is a great magazine of Celtic studies, in which one comes upon a seventeenth century Irish poem beside specimens of Gaelic, as spoken in the Isle of Skye ; an article on "Arthurian Motifs in Gaelic Literature" following "Lucius Rex and Eleutherius Papa"; an examination by Mrs. A. S. Green of Henry VIII.'s title, "King of Ireland " next an Irish poem containing instructions for a King. There are thirty-eight articles in the Miscellany, and amongst them a contribution in the third language of Wales-a Romani folk-tale, "The Leaves that Hung but never Grew," with a translation. This great volume of Celtic studies is enriched by a portrait of the scholar who has made himself the champion of the Celtic name.

Of the contributions that have poetry for their kernel, two at least, have a living interest for a lover of literature-a sequence of dramatic lyrics, and a short poem, "The Dove of Mother-I-Roy." Curiously enough, both are attributed to women. "The Dove of Mother-I-Roy" belongs to the seventeenth century. Like the bulk of the poetry of the period it is a lament for the ruin of a noble family.

*A Miscellany presented to Kuno Meyer by some of his Friends and Pupils on the occasion of his appointment to the Chair of Celtic in the University of Berlin. Dublin, Hodges Figgis and Co. $16 s$. 


\section{A CELTIC MISCELLANY}

The maker of the poem hears a dove coo from Mother-l-Roy, the ruin of O'Connor Conconroy's mansion in the North-West of Clare :-

An omen of grief is thy song, little dove, my heart dies within me on its account. Thou hast coaxed the tears from my eyes; a pity it is thou wert not silent. That the spacious halls of the mansion of $\mathrm{Ua}$ Roigh are left empty beneath thee, is it this that makes thee light-hearted, that thou canst not cease thy singing? Or is it sorrow that torments thee, $O$ dove, little pied dove from Spain, that in the place where we used to gather in our numbers, I now see but thee alone.

The mansion is solitary to-night, where I used to hear the cry of harp and chorus, the cry of spacious feasting at the wine, the cry of the tenants paying their dues, the cry of the warriors sharpening their weapons, the cry of the " scot" at the time of their division, the cry of the oars in the harbour, the cry of the gulls in the ocean cave ; the cry of the chess played apace, the harsh cry of the sages at their old books, the sweet-voiced cry of fair women, such as understood the meaning of our questions. It was the daughter of Domhnall that bore me, and gave me my understanding; how should it be other than an omen of grief to me that she is without heir or grandson?

$O$ little dove of the sorrowful strain in yonder hall, sad it is that the famous pile beneath thee should lie thus in ruins-the hill of proud Ua Roigh of the pinnacled walls, without wassail, without well-wrought lays or wielding of weapons.

The sequence of eleven dramatic lyrics which Dr. Bergin has edited is attributed to Queen Gormlaith. The husband who is lamented in several of these noble and poignant poems was Niall Glundub, who was killed in a battle with the Norse in 919. The first lyric is in three stanzas, and it opens and closes with the line "This is mournful, O Fort of Kings." The second lyric has a passion and pathos that make it moving after a thousand years :-

The din of the wedding is in yon house, to whosoever it brings glee, there is one to whom it brings sorrow, while listening to every loud voice. Though yonder woman rejoices at the binding of her contract, alas for one whom the world cheats-I once got the like. Thou hast merited reproach from me, $O$ Ruler of the lasting World. Why hast thou slain Aed's son? For he was no foul tyrant. . . . . O coverlet wherein Niall was wont to sleep, to which the men of Oriel would come, it is a sore grief to me that thou, $O$ white one, $O$ 


\section{THE IRISH REVIEW}

bed, art without thy darling. His tunic I am loth to behold after my short-lived hero, while he to whom it was a goodly ornament is lying dead in Kells. Thus spake Niall to me as he went westward from Armagh : "Whichever of us should first depart, Gormlaith, where shall that one go?" "I would give thee good counsel, O King of Eoghan's race, let us be carried to the soil of cool Aileach and buried in one grave." "If thou, O fair Gormlaith, shouldst first go into the earth, I am no man to wed a wife, but to be weeping without laughter."

Gormlaith had a stormy life. She was wedded to two husbands before she came to Niall, whose death she laments so constantly. After her husband's death her son was drowned, and she mournfully recites the pedigree of the boy "whose death darkens the sun. White was his neck, white his foot-my heart has found nought so heavy." Several of the poems express revolt against poverty and dependance : "Often the brambles take hold of me, twisting about my rags; the thorn is no friend to me, and the briar is a foe." "Should I say the raven is black the Leinsterman would say it was white ; be my walk crooked or straight, they would say it is not right." "I had poets in my pay until the Lord took away my wealth." Gormlaith was espoused to three Kings. "After all which royal marriages," says a medieval annalist, "she begged from doore to doore, forsaken of all her friends and allies, and glad to be relieved by her inferiours." Her death is in keeping with the pathos of the poems. "Shee dreamed that she sawe King Neale Glunduffe, whereupon she gott up and sate in her bedd to behould him, whom he for anger would forsake and leave the chamber; and hee was departing in that angry motion (as she thought) shee gave a snatch after him, thinking to have taken him by the mantle, to keep him with her, and fell upon one of the beddstickes of the bedd, that it pearsed her brest, eaven to her very hart, which received no cure until she Died thereof." Dr. Bergin is tempted to regard the lyrical sequence as a fragment of the lost historical romance, "The Love of Gormlaith for Niall," mentioned in one of the ancient books.

Professor Henderson makes a living Arthurian ballad the subject of a very interesting contribution. The ballad is in Scots-Gaelic, and is sung in South-Uist to an air such as is associated with the 


\section{A CELTIC MISCELLANY}

Ossianic ballads. It tells how the King of Britain dreamed of a woman who was the loveliest in the world, and how Sir Galvain (Gawain) went to seek her. In a Castle in the middle of the sea he found her. She lulled him to sleep with song and the music of her harp, and then with his own sword beheaded him. The ballad is known to the Gaelic speakers of the Islands as "Am Bron Binn." "The Melodious Sorrow." The fact that this long-descended story is living still amongst the people of far-away Uist emphasises what many contributions to the In iscellany suggest- that a variety of culture exists in the British Islands. That the various minor cultures are being weakened in the interest of a single dominant one is a great intellectual loss.

P.C. 